\title{
POLA PERMUKIMAN SUKU DAYAK KENYAH DI KELURAHAN BUDAYA PAMPANG KOTA SAMARINDA
}

\section{(SETTLEMENT PATTERNS OF THE DAYAK KENYAH TRIBE IN PAMPANG CULTURAL VILLAGE, SAMARINDA CITY)}

\author{
Puput Wahyu Budiman*, Sudaryono** \\ * Magister Perencanaan Wilayah dan Kota, Fakultas Teknik Universitas Gadjah Mada, Yogyakarta \\ Jalan Grafika No. 2, Yogyakarta, Indonesia \\ Email:puputwahyubudiman@mail.ugm.ac.id \\ *** Departemen Teknik Arsitektur dan Perencanaan, Fakultas Teknik, Universitas Gadjah Mada, Yogyakarta \\ Jalan Grafika No. 2, Yogyakarta, Indonesia
}

Diterima: 19 Mei 2021; Direvisi: 24 Juni 2021; Disetujui: 29 Juni 2021

\begin{abstract}
ABSTRAK
Kelurahan Budaya Pampang merupakan salah satu kawasan di Kota Samarinda yang memiliki sejarah, budaya, tradisi dan permukiman yang unik karena mengandung nilai - nilai kearifan lokal dalam pembentukannya. Penelitian ini bertujuan mengetahui pola ruang permukiman yang terbentuk dengan menggunakan metode induktif kualitatif dengan pendekatan fenomenologi. Hasil penelitian menunjukan bahwa pola permukiman yang terbentuk terdiri dari elemen air terjun ( $u$ 'ung) di sebelah utara sebagai zona sakral dan lepoq (permukiman) di sebelah selatan sebagai zona profan.
\end{abstract}

Kata kunci: Kelurahan Budaya Pampang, permukiman,, suku Dayak.

\begin{abstract}
Pampang Cultural Village is one of the areas in Samarinda City which has a unique history, culture, tradition and settlement because it contains local wisdom values in its formation. This study aims to determine the pattern of residential spaces formed using qualitative inductive methods with a phenomenological approach. The results showed that the settlement pattern formed consisted of waterfall elements (u'ung) in the north as a sacred zone and lepoq (settlements) in the south as a profane zone.
\end{abstract}

Keywords: Kelurahan Budaya Pampang, settlements, Dayak Kenyah tribe.

\section{PENDAHULUAN}

Kebudayaan adalah seluruh sistem gagasan dan rasa, Tindakan serta karya manusia yang dihasilkan manusia dalam kehidupan bermasyarakat (Koentjaraningrat, 1996). Terbentuknya suatu pola permukiman sangat dipengaruhi oleh budaya masyarakat setempat. Masyarakat dalam membentuk lingkungan huniannya yang baru di tempat yang berbeda dari tempat asalnya, akan selalu mengikuti kebudayaan dan sistem kepercayaan yang masyarakat pegang teguh di lingkungan hunian yang lama. Hal ini dapat dilihat pada upaya masyarakat tersebut dalam memodifikasi lingkungan huniannya yang baru (Sumintardja,1999).

Kelurahan Budaya Pampang merupakan desa adat yang memiliki berbagai potensi pariwisata yang terdiri dari berbagai atraksi budaya yang menjadi ciri khas kelurahan ini (Sulisthio and Nurdiah 2013). Desa adat tidak hanya menawarkan potensi wisata berupa tarian maupun pemandangan alam yang unik namun juga menawarkan eksotisme hunian dan cara hidup penghuninya (Kumurur and Damayanti 2009). Ragam budaya pada desa adat menjadi suatu faktor penarik wisatawan untuk berkunjung sekaligus menjadi tantangan dalam 
mempertahankan nilai budaya yang ada dalam suatu desa adat dari pengaruh luar (Nilasari, Irianto Sitindjak, and Wardani 2019). Berkembangnya pariwisata dalam suatu masyarakat adat juga mempengaruhi pola penyusunan ruang di dalamnya (Wibawa, Samekto, and Gelgel 2019) yang memberikan ciri khas tertentu dalam bentuk fisik maupun non fisik (Agustian et al. 2020).

Masyarakat Dayak pada umumnya hidup dari berladang dan berburu pada lahan - lahan di hutan (Singarimbun 2013). Masyarakat suku Dayak Kenyah di Kelurahan Budaya Pampang berasal dari Apokayan, seperti pada suku Dayak lainnya merupakan masyarakat yang sangat teritorial terhadap wilayahnya (Coomans 1987) terutama dalam mempertahankan lahan buruan dan berladang. Di masa lalu, dalam mempertahankan wilayahnya sering terjadi konflik antar sesama suku Dayak sehingga suku yang kalah melakukan migrasi untuk menghindari konflik berkepanjangan. Selain faktor perebutan lahan, faktor ekonomi juga menjadi alasan masyarakat Dayak melakukan migrasi. Migrasi yang dilakukan menyebabkan adanya adaptasi masyarakat terhadap lingkungan barunya sehingga terbentuk kebiasaan baru yang juga berpengaruh terhadap huniannya (Mazza and Punzo 2016). Kebiasaan baru ini juga mempengaruhi kebiasaan dalam bermukim suku Dayak Kenyah di kelurahan Budaya Pampang yang membentuk pola baru yang berbeda dari asalnya di Kecamatan Apokayan Kalimantan Utara (Prasetya Pergitawati, Antariksa, and Muhammad Ridjal 2014) sehingga menarik untuk dikaji lebih mendalam pola permukiman yang terbentuk ini.

Pengaruh budaya ditunjukkan dalam tatanan permukiman yang membentuk pola - pola tertentu yang khas (Rini Dwi Ari and Antariksa 2005). Pola khas ini dibentuk dari nilai - nilai yang dianut bermasyarakat terutama dilandasi oleh kepercayaan sebagaimana terjadi di Bali yaitu falsafah dalam agama hindu menjadi landasan dalam penentuan tata ruang permukiman (Dwijendra 2008). Selain agama hindu, nilai - nilai dalam falsafah agama islam juga mempengaruhi bentuk suatu permukiman sehingga membentuk suatu pola yang unik (Meria Burhan, Antariksa, and Meidiana 2008)

1. Permukiman (lepoq) masyarakat Suku Dayak Kenyah memiliki ciri khas tersendiri yang berbeda dari asalnya (Prasetya Pergitawati, Antariksa, and Muhammad Ridjal 2014). Perbedaan kebiasaan dalam bermukim dipengaruhi oleh bermacam - macam aspek seperti geografis (Wicaksono and Kusdiwanggo 2016), dan nilai - nilai kearifan lokal yang dianut (Tri Adiputra et al. 2016). Oleh karena itu penelitian ini bertujuan untuk menemukan pola permukiman yang terbentuk dari fenomena - fenomena keruangan yang ada yang mengandung nilai - nilai kearifan lokal suku Dayak Kenyah sehingga nilai dan pola yang digali dapat menjadi masukan bagi perkembangan penataan ruang di Provinsi Kalimantan Timur.

\section{METODE}

Metode penelitian yang akan digunakan dalam penelitian Ini adalah metode induktif kualitatif dengan pendekatan fenomenologi dengan analisis berupa observasi mendalam terhadap berbagai fenomena keruangan yang terjadi (Pahude et al. 2017). Selain melakukan pengamatan secara mendalam, juga dilakukan wawancara kepada 10 informan yang dipilih dengan teknik purposive sampling secara snowball (Sugiyono 2015) sehingga didapatkan 9 informan.

\section{HASIL DAN PEMBAHASAN}

Pola permukiman masyarakat suku Dayak Kenyah di Kelurahan Budaya Pampang dapat diidentifikasi berdasarkan tiga aspek, yaitu aspek sosial budaya pembentuk permukiman (Kumurur and Damayanti 2009), pola ruang hunian mikro (Kumurur and Damayanti 2009), dan ruang permukiman secara makro (Meria Burhan, Antariksa, and Meidiana 2008) : 


\section{Aspek Sosial Budaya Pembentuk ruang Permukiman}

Aspek sosial budaya pembentuk permukiman terdiri dari unsur yaitu sejarah terbentuknya kampung, kegiatan mata pencaharian, kegiatan sosial budaya dalam permukiman, dan aturan adat yang berlaku.

Sejarah terbentuknya kampung Pampang tidak lepas dari asal -usul masyarakat suku Dayak Kenyah di Kelurahan Budaya Pampang itu sendiri. suku Dayak Kenyah Kelurahan Budaya Pampang berasal dari Apokayan, Kabupaten Malinau Kalimantan Utara yang berbatasan langsung dengan Negara Bagian Serawak Malaysia bermigrasi di tahun 1960 dengan alasan yaitu mencari penghidupan yang lebih layak. Di masa awal terbentuknya kampung Pampang, masyarakkat suku Dayak Kenyah tinggal dalam hunian berupa pondok (lepou) dengan yang tersebar mendekati lokasi ladang dan hutan tempat berburu sebagaimana terdapat pada gambar 1.

Masyarakat suku Dayak Kenyah terdiri dari 6 klan yaitu klan lepoqtau, klan bakung, klan maqjanan, klan maqlasan, klan umaqbaqa, dan klan lepoqbau. Di masa awal kedatangannya sering terjadi konflik antar klan sehingga timbul suatu kesadaran untuk meningkatkan persatuan antar sesama klan demi eksistensi suku Dayak Kenyah yang ditandai dengan suatu simbol yaitu lamin adat sebagai sarana aktivitas budaya dengan semboyan pemung tawai (satu pikiran satu tujuan). Kemudian beberapa dekade berikutnya terutama pada kurun waktu tahun 1980an, Adanya kegiatan budaya pada lamin adat ini menarik wisatawan baik mancanegara maupun domestik sehingga mata pencaharian utama bergeser dari yang semula berladang dan berburu menjadi jasa pariwisata. Aktivitas berburu dan berladang tetap menjadi salah satu mata pencaharian bahkan menjadi bagian dari atraksi wisata. Keberadaan lamin adat sebagai pusat aktivitas budaya dan sarana pariwisata mempengaruhi bentuk permukiman yang semula menyebar menjadi mengelompok di Kelurahan Budaya Pampang (Gambar 1).

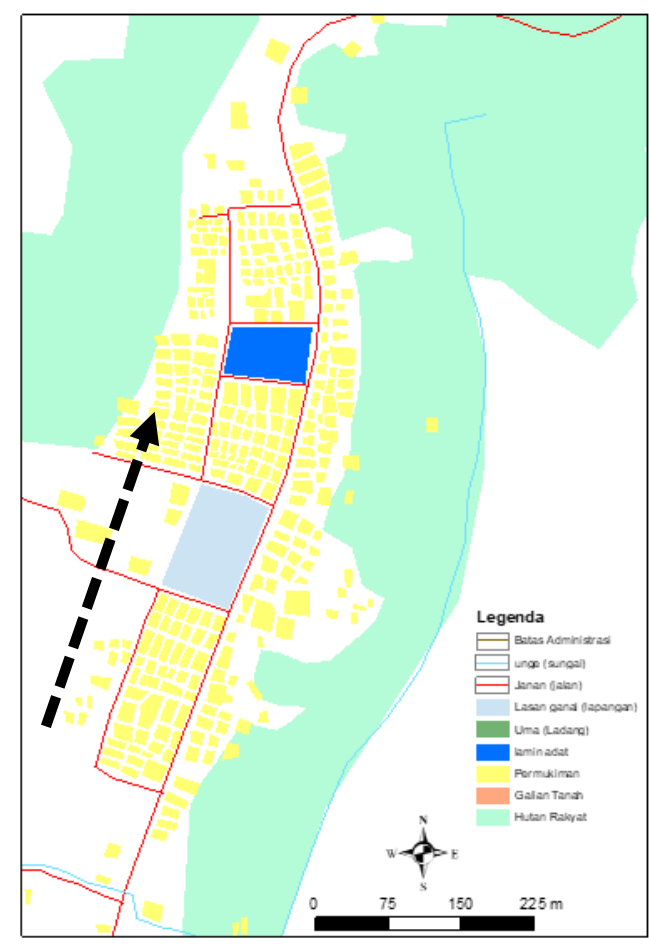

Gambar 1. Permukiman bermula dari selatan menuju utara Sumber: Hasil Analisis GIS (2021)

Masyarakat Dayak pada umumnya hidup dari berladang dan berburu pada lahan - lahan di hutan (Singarimbun 2013). Pada masa merintis kampung, masyarakat suku Dayak Kenyah 
di Kelurahan Budaya Pampang, memiliki mata pencaharian utama berladang dan berburu yang masih berlangsung hingga saat ini (gambar 2 dan gambar 3).

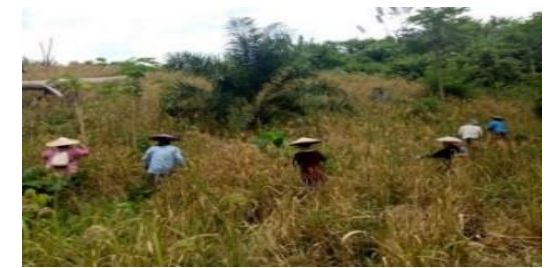

Gambar 2. Aktivitas Bahuma (berladang) Sumber: Dokumentasi (2020)

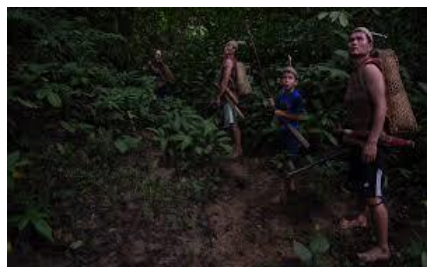

Gambar 3. Aktivitas berburu Sumber: Dokumentasi (2020)

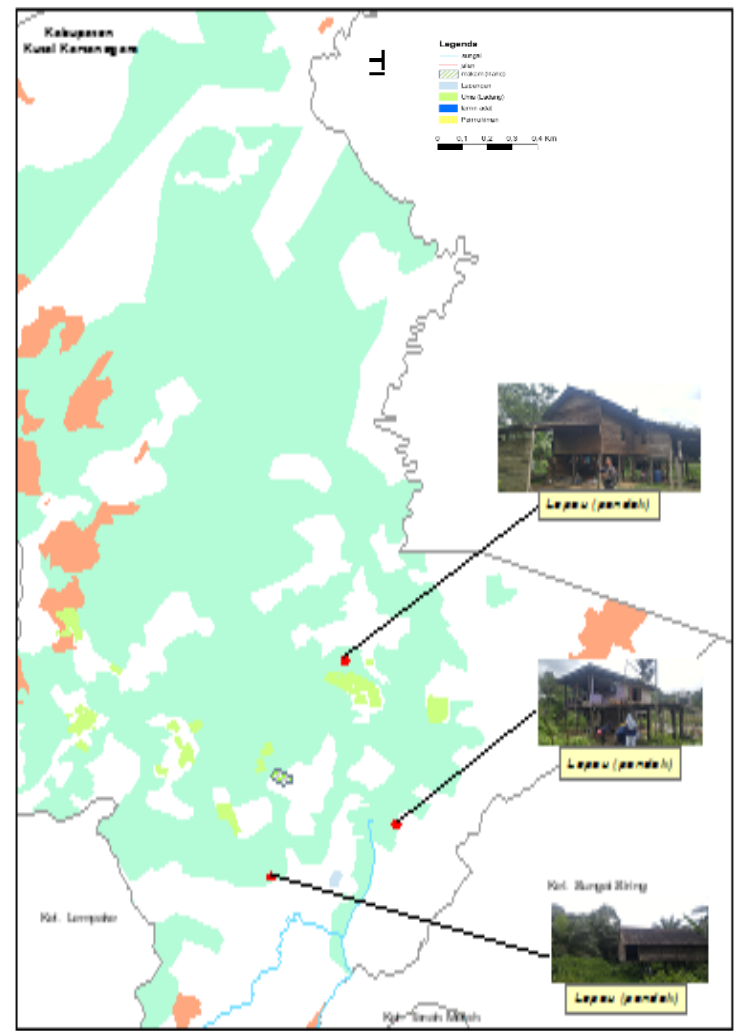

Gambar 4. Pola menyebar di masa berburu Sumber: Hasil Analisis GIS (2021) 


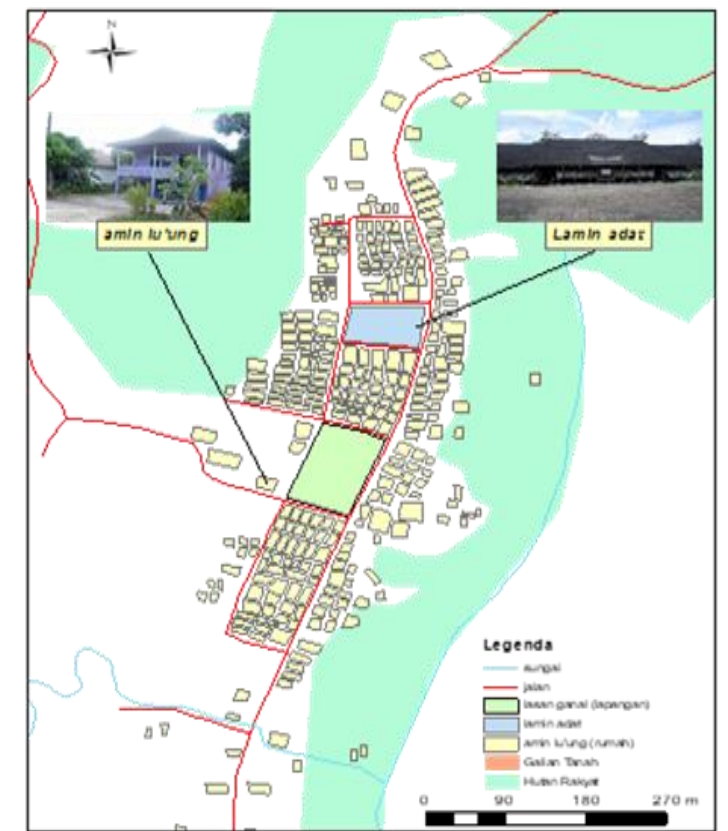

Gambar 5. Pola mengelompok pada masa pariwisata Sumber: Hasil Analisis GIS (2021)

Cara berladang (bahuma) masyarakat suku Dayak Kenyah memiliki keunikan tersendiri disebut gilir balik. Dalam berladang terdapat aturan yaitu tiap kepala keluarga tidak diperkenankan memiliki lebih dari 5 petak bidang tanah. Pengolahan bidang tanah juga dianjurkan satu petak tiap tahunnya dan pada tahun ke 6 diharapkan kembali mengolah petak pertama dengan asumsi petak tanah pertama telah subur kembali (gambar 6). Aturan ini menjadi semacam hukum yang berlaku dalam mengolah lahan sehingga jika ada yang melanggar aturan ini akan dikenakan denda berupa barang-barang adat. Menghemat lahan untuk berladang (bahuma) juga diterapkan dalam mendirikan hunian yang mengedepankan penghematan lahan sehingga permukiman terlihat kompak.

$T$ T IJr $k x:-1$

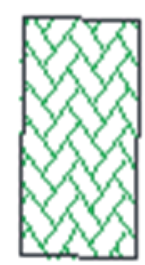

「ลาเก 嶉 2

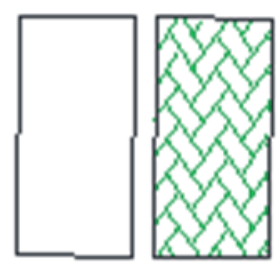

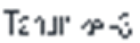
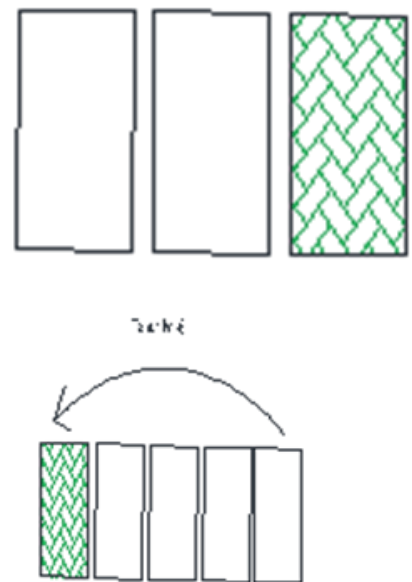

Gambar 6. Ilustrasi bahuma (berladang) dengan cara gilir balik Sumber: Hasil Analisis (2021)

Kegiatan sosial budaya yang terjadi dalam permukiman dilakukan pada ruang - ruang permukiman menghasilkan pola tertentu. Berbagai aktivitas sosial budaya yang menciptakan ruang - ruang permukiman diantaranya dapat dilihat pada gambar berikut. 
Ritual kahwin merupakan ritual yang dilakukan kepada masyarakat suku Dayak Kenyah yang akan melangsungkan pernikahan yang terdiri dalam 3 tahap yaitu alaq leto (menjemput pengantin), pekatuq (memberi nasihat) dan resepsi. Dalam tahap alaq leto, ruang yang digunakan adalah rumah pengantin pria (amin lu'ung), jalan (janan) dan rumah pengantin wanita (amin lu'ung). Untuk tahap pekatuq, ruang yang digunakan ialah rumah pengantin pria yang terjadi pada ruang tamu (dalem). Kemudian untuk tahapan resepsi, ruang yang digunakan ialah rumah pengantin pria (amin lu'ung), jalan (janan), dan lamin adat sehingga menghasilkan suatu pola yang memanjang secara linier terhadap jalan dan mengelompok mendekati lamin adat. Secara sederhana penggunaan ruang tahapan ritual kahwin dapat dilihat pada gambar 7 berikut:

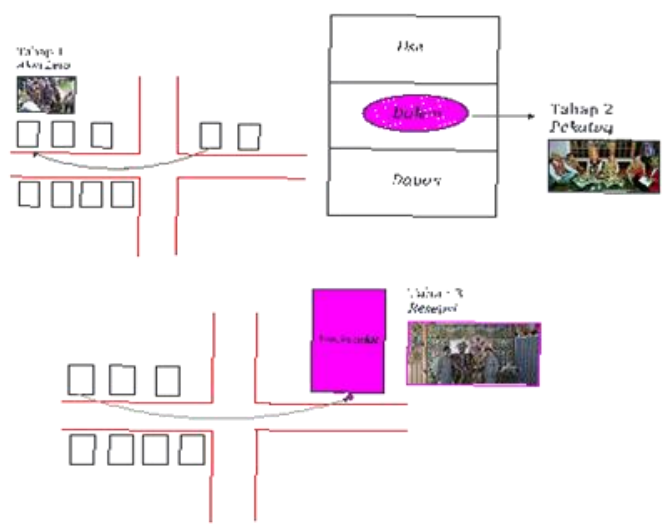

Gambar 7. Pola ruang dalam ritual kahwin (perkawinan) Sumber: Hasil Analisis (2021)

Panen raya (ramai lepaq ajau) merupakan acara tahunan yang dilakukan sebagai wujud rasa syukur warga suku Dayak Kenyah di Kelurahan Budaya Pampang atas hasil panen yang diberikan oleh Tuhan Yang Maha Esa. Acara ini dimulai dengan iring -iringan warga dengan membawa hasil panen dengan alunan alat musik sape dari amin lu'ung ataupun lepou padai (pondok menyimpan padi), kemudian di janan (jalan) dan berakhir di lamin adat diikuti taritarian. Kegiatan ramai lepaq ajau membentuk pola permukiman linier dengan jalan dan mengelompok mendekati lamin adat. Acara ini merupakan acara adat terbesar sehingga menarik perhatian berbagai wisatawan dan pejabat pemerintahan sebagaimana dijelaskan pada gambar 7 berikut ini:

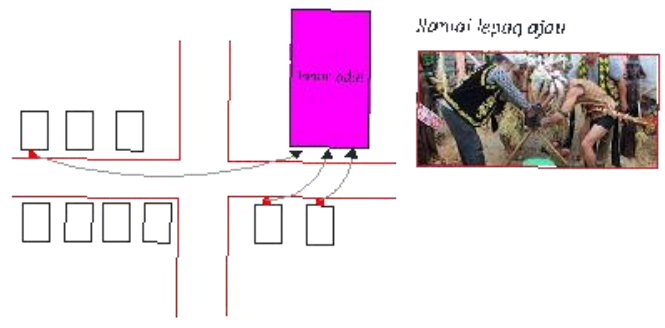

Gambar 8. Pola ruang dalam kegiatan ramai lepaq ajau Sumber: Hasil Analisis (2021)

Kelahiran anak suku Dayak Kenyah di Kelurahan Budaya Pampang ditandai dengan ritual ngabayen uyen ngadananak. Acara ini biasanya berlangsung di amin lu'ung. Adapun ruang yang digunakan ialah dapon (dapur) sebagai tempat mengolah makanan untuk konsumsi acara syukuran, dan dalem (ruang keluarga) sebagai tempat menggelar acara inti seperti gambar 8 dibawah ini: 

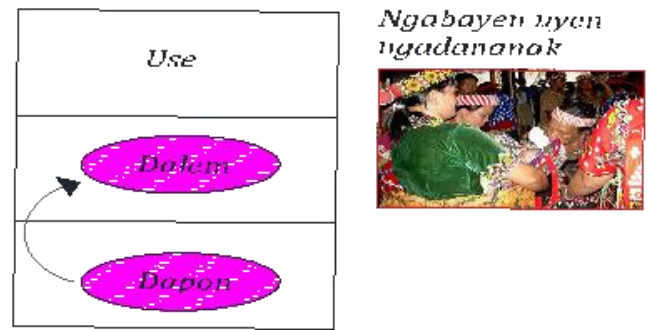

Gambar 9. Pola ruang dalam kegiatan ngabayen uyen ngadananak Sumber: Hasil Analisis (2021)

Anjuran atau nasihat ini menjadi pegangan dalam hidup bermasyarakat yang terwujud dalam semboyan pegayan kuaq yang secara harafiah berarti gotong royong atau tolong menolong. Gotong royong merupakan bentuk sikap saling membantu antar sesama suku Dayak Kenyah, yang mengutamakan respon cepat untuk menolong keluarga maupun kerabat yang mengalami kesusahan. Untuk memungkinkan ini maka lokasi hunian antar sesama kerabat yang masih satu keluarga besar berdekatan sehingga membentuk pola permukiman yang mengelompok sebagaimana dapat dilihat pada gambar 10 .

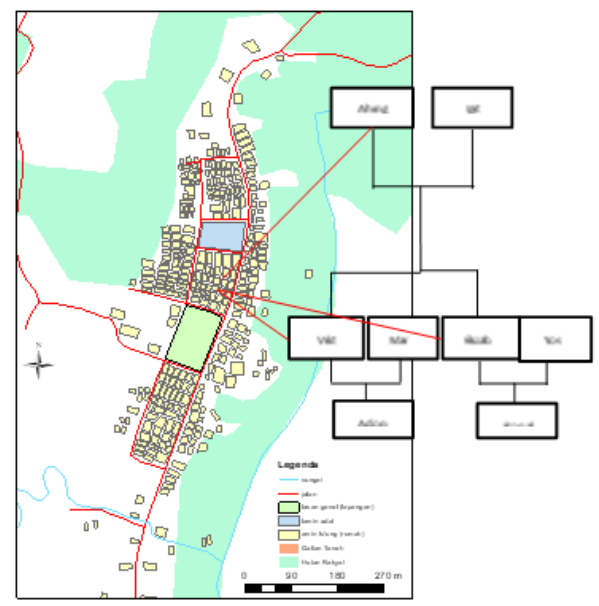

Gambar 10. Letak hunian berdasarkan kekerabatan Sumber: Hasil Analisis (2021)

Hasil temuan di lapangan, aturan adat yang berlaku mempengaruhi pola permukiman masyarakat suku Dayak Kenyah di Kelurahan Budaya Pampang. Hukum adat di Kelurahan Budaya Pampang bersumber dari falsafah uyen tiga (rumah bersama). Falsafah ini terdiri dari falsafah uyen tiga nangaliku kelunan (hubungan suku Dayak Kenyah dengan suku lain, sang pencipta dan alam sekitar) dan falsafah uyen tiga nangaliku panaq (hubungan sesama suku Dayak Kenyah). Falsafah ini berisi nasihat, larangan, semboyan, ritual maupun denda yang menjadi aturan tidak tertulis dalam bentuk hukum adat.

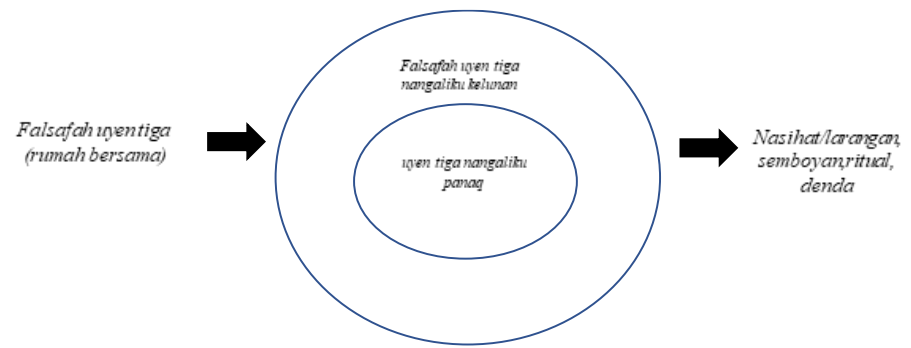

Gambar 11. Ilustrasi falsafah uyen tiga 
Beberapa hukum adat yang menjadi landasan dalam bermukim masyarakat suku Dayak Kenyah ialah semboyan pebeka udip (hidup bersatu). Semboyan ini mengajarkan untuk hidup bersatu dengan suku bangsa lain disebabkan suku bangsa lain merupakan bagian dari konsep rumah bersama uyen tiga (gambar 11). Jika terjadi konflik maka harus segera diselesaikan dengan saling memberi denda bagi yang bertikai dalam bentuk mandau. Hukum adat selanjutnya adalah larangan dalam membangun hunian dekat air terjun ( $u$ 'ung) karena air terjun dianggap sebagai wilayah suci sehingga terbentuk ruang budaya yang dianggap sakral menyebabkan terdapat ruang yang tidak boleh dihuni masyarakat sebagaimana dapat dilihat pada gambar 13 .

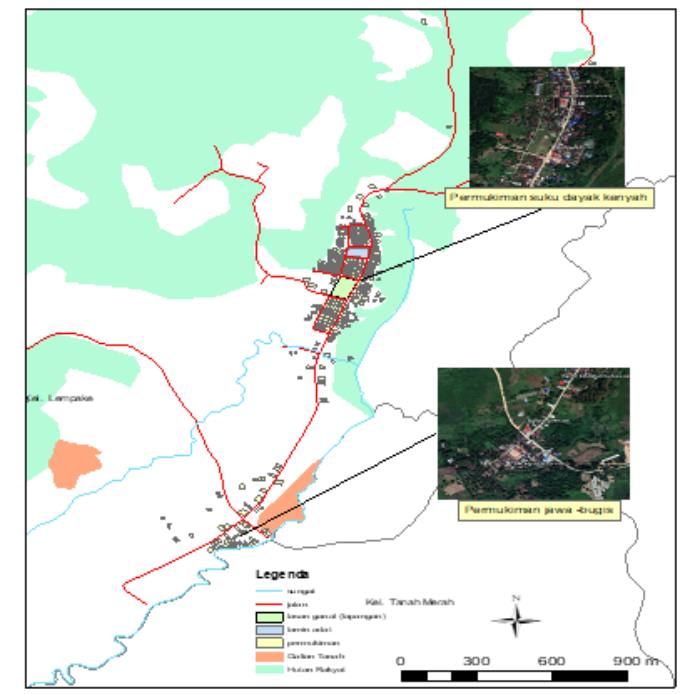

Gambar 12. Pola ruang dalam Semboyan pebeka udip (hidup bersatu) Sumber : Hasil Analisis (2021)

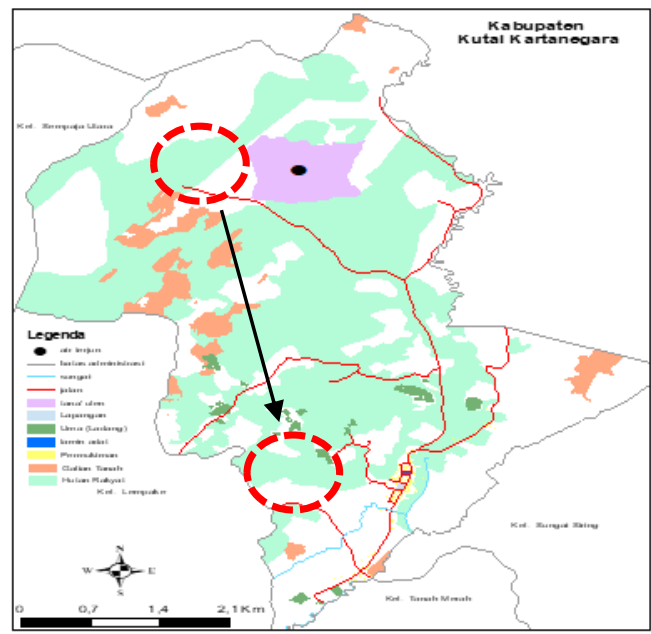

Gambar 13. Larangan membangun hunian di sekitar $u$ 'ung (air terjun) hunian menjauh ke selatan Sumber: Hasil Analisis (2021)

\section{Pola ruang hunian mikro}

Hunian masyarakat suku Dayak Kenyah di Kelurahan Budaya Pampang terdiri dari 2 tipe rumah yaitu amin lu'ung yang berfungsi sebagai tempat tinggal dan lamin adat (umaq dadoq) sebagai sarana aktivitas budaya. Dahulu umaq dadoq berfungsi sebagai rumah komunal yang berisi 5 hingga 12 kepala keluarga namun dengan adanya konsensus untuk mewujudkan persatuan sesama suku Dayak Kenyah maka lamin adat berfungsi sebagai simbol persatuan 
antara klan yang ada sekaligus menjadi pusat aktivitas budaya sebagai wujud semboyan pemung tawai. Adapun ruang dalam amin lu'ung (hunian pribadi) dan lamin adat dijelaskan pada gambar berikut.
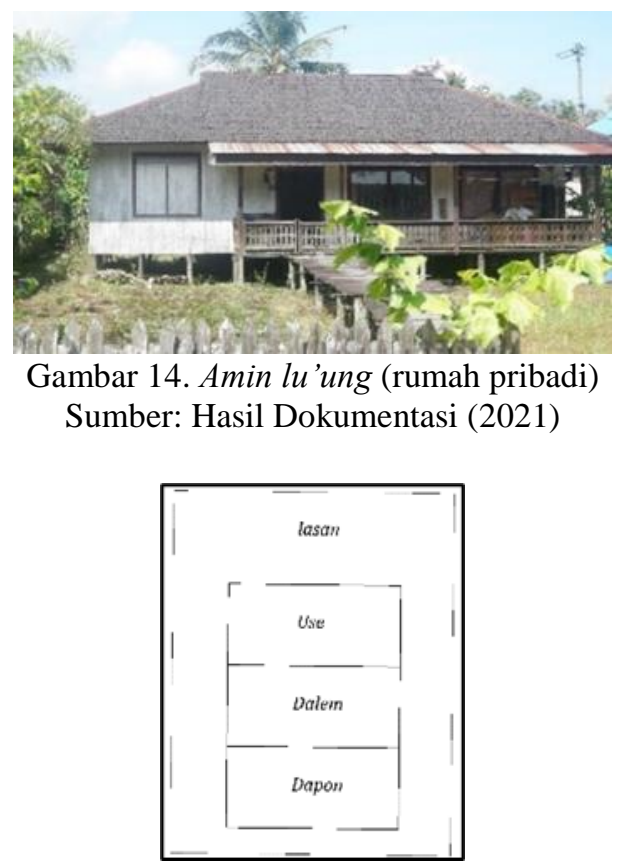

Gambar 15. Pola ruang dalam Amin lu'ung (rumah pribadi)

Sumber: Hasil Dokumentasi (2021)

Berdasarkan gambar 15 diatas, diketahui bahwa polar uang dalam hunian amin lu 'ung terdiri dari lasan atau halaman, use atau teras, dalem atau ruang tengah dan dapon atau dapur.

Amin lu'ung merupakan hunian berbentuk panggung. Orientasi timur menandakan rumah keturunan bangsawan dan barat menandakan masyarakat biasa. Janan (jalan) merupakan ruang publik yang sangat penting yang menghubungkan tiap elemen permukiman dalam aktivitas sosial budaya. Lasan ganal (lapangan)l merupakan ruang terbuka tempat warga berkumpul dan melakukan aktivitas budaya. Li'ang (makam) terletak di sebelah timur lepoq merupakan tempat peristirahatan terakhir warga yang sudah meninggal, liang berorientasi ke barat sebagai tanda matahari terbenam sebagai wujud arah kepergian orang yang telah meninggal Peletakan keempat penjuru mata angin dilakukan para tetua yang dianggap memiliki kemampuan gaib

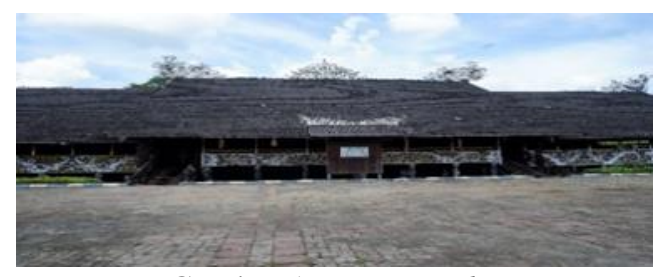

Gambar 16. Lamin adat

Sumber: Hasil Dokumentasi (2021) 


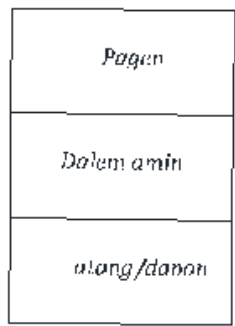

Gambar 17. Pembagaian ruang dalam lamin adat

Sumber: Hasil Dokumentasi (2021)

Adapun pola ruang pada lamin adat terdiri dari pagen atau teras, dalem amin atau ruang tengah dan atang atau dapon disebut juga dapur. Nilai - nilai dalam lamin adat diadaptasi dalam bentuk pola ruang mikro di dalam permukiman yaitu perkampungan pampang memiliki suatu pusat spiritual dan budaya yang berada ditengah kampung yang dikelilingi oleh rumah rumah pribadi yang kedudukannya setara. Lamin adat diibaratkan sebagai dalem amin sebagai pusat rumah dan amin lu'ung diibaratkan ruang-ruang lainya seperti dapon, bilik, use, dan lasan yang tidak bersekat dan kedudukannya setara.

\section{Pola Ruang Permukiman Makro}

Permukiman tradisional masyarakat suku Dayak Kenyah di Kelurahan Budaya Pampang terdiri memiliki beberapa elemen fisik pembentuk permukiman. Permukiman Kelurahan Budaya Pampang dibentuk oleh berbagai unsur fisik pembentuk permukiman. Berdasarkan hasil observasi dilapangan, beberapa unsur-unsur pembentuk permukiman pampang diantaranya dapat dilihat pada gambar 18 .

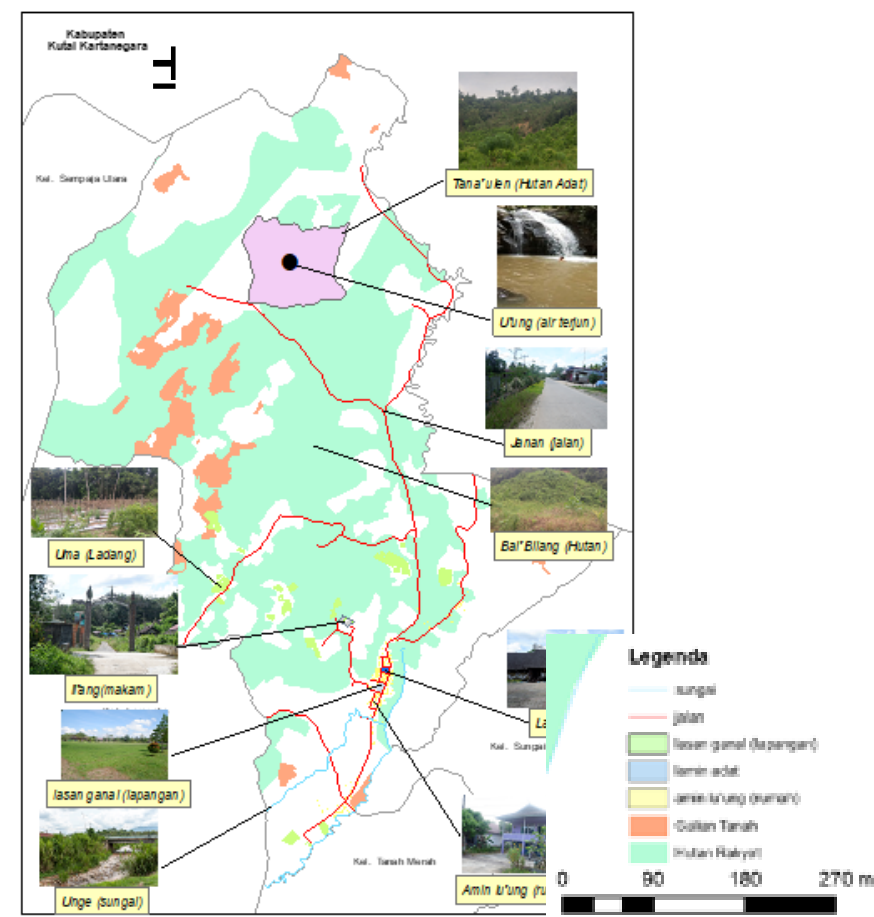

Gambar 18. Elemen fisik dalam pembentuk permukiman

Sumber: Hasil Analisis GIS (2021)

Berdasarkan gambar 13 diatas, beberapa unsur fisik pembentuk permukiman dapat dijelaskan sebagai berikut. Lamin adat terletak di sebelah selatan merupakan pusat aktivitas budaya sebagai lambang persatuan sesama suku Dayak Kenyah. Amin lu'ung merupakan hunian berbentuk panggung. Orientasi timur menandakan rumah keturunan bangsawan dan 
barat menandakan masyarakat biasa. Janan (jalan) merupakan ruang publik yang sangat penting yang menghubungkan tiap elemen permukiman dalam aktivitas sosial budaya. Lasan ganal (lapangan) merupakan ruang terbuka tempat warga berkumpul dan melakukan aktivitas budaya. Li'ang (makam) terletak di sebelah timur lepoq merupakan tempat peristirahatan terakhir warga yang sudah meninggal, liang berorientasi ke barat sebagai tanda matahari terbenam sebagai wujud arah kepergian orang yang telah meninggal Peletakan keempat penjuru mata angin dilakukan para tetua yang dianggap memiliki kemampuan gaib.

\section{KESIMPULAN}

Bentuk kearifan lokal masyarakat suku Dayak Kenyah di Kelurahan Budaya Pampang tercermin dalam permukiman tradisional (lepoq) dan lingkungannya. Pola permukiman yang terbentuk dari nilai - nilai dalam budaya yaitu memanjang secara linier terhadap jalan, berkelompok mendekati lamin adat dan cenderung ke selatan menjauhi air terjun (u'ung). Hal ini menyebabkan permukiman masyarakat suku Dayak Kenyah memiliki ciri khas tertentu yaitu disebelah utara merupakan air terjun ( u'ung) dan hutan adat (tana' ulen) yang dianggap suci yang merupakan zona sakral dan sebelah selatan merupakan zona profan (manusia) yang diwakili oleh lepoq yang terdiri dari kumpulan amin lu'ung (rumah pribadi) dan lamin adat sebagai pusat budaya.

\section{REKOMENDASI}

Adapun rekomendasi pada penelitian kali ini adalah sebagai berikut:

- Perlu adanya kajian lebih mendalam mengenai konsep yang melandasi terbentuknya permukiman suku Dayak Kenyah di Kelurahan Budaya Pampang.

- Perlu upaya pelestarian pola dan bangunan tradisional terutama lamin adat dan amin lu'ung sebagai kekayaan budaya suku Dayak Kenyah.

- Perlu penguatan peran lembaga adat dalam hal partisipasi masyarakat.

\section{DAFTAR PUSTAKA}

Agustian, Endy, Rini Rachmawati, R. Rijanta, and Agus Joko Pitoyo. (2020). "Multi-Ethnic Settlement Concept in Denpasar City, Bali, Indonesia." Journal of Physics: Conference Series 1655 (1). https://doi.org/10.1088/1742-6596/1655/1/012132.

Coomans, M. (1987). Manusia Daya: Dahulu, Sekarang, Masa Depan. Gramedia. https://books.google.co.id/books?id=sM8bAAAAMAAJ.

Dwijendra, Ngakan Ketut Acwin.(2008). Arsitektur Rumah Tradisional Bali: Berdasarkan Asta Kosala-Kosali. Balira: Udayana University Press.

Koentjaraningrat. 1996. Kebudayaan, Mentalitas dan Pembangunan. Jakarta: PT Gramedia.

Kumurur, Veronica A, and Setia Damayanti. 2009. Pola Perumahan Dan Pemukiman Desa Tenganan Bali. Jurnal Sabua 1 (1): $1-7$. https://ejournal.unsrat.ac.id/index.php/SABUA/article/view/246/193.

Mazza, Angelo, and Antonio Punzo. (2016). Spatial Attraction in Migrants' Settlement Patterns in the City of Catania. Demographic Research 35 (July): 117-38. https://doi.org/10.4054/DemRes.2016.35.5.

Meria Burhan, Issana, Antariksa, and Christia Meidiana. (2008). Pola Tata Ruang Permukiman Tradisional Gampong Lubuk Sukon, Kabupaten Aceh Besar." Arsitektur E-Journal 1 (3): 172-89. http://antariksa.lecture.ub.ac.id/2008/11/. 
Nilasari, Poppy Firtatwentyna, Ronald Hasudungan Irianto Sitindjak, and Laksmi Kusuma Wardani. (2019). Tenganan Indigenous Village as a Cultural Historical Tourism Destination in Bali Island, Indonesia."African Journal of Hospitality, Tourism and Leisure 2019 (Special Issue): 1-7. http://repository.petra.ac.id/18916/1/Publikasi1_03007_6071.pdf.

Pahude, Mansur S, Didik Kristiadi, Universitas Gadjah Mada, Universitas Gadjah Mada, and Universitas Gadjah Mada. (2017). "Konsep Ruang Permukiman Tradisional Sebagai Basis Wisata Di Desa Sabang Kabupaten Toli-Toli." In Prosiding Seminar Nasional Dan Call For Paper Ekonomi Dan Bisnis (SNAPER-EBIS 2017), 2017:27-28. Jember. https://jurnal.unej.ac.id/index.php/prosiding/article/view/6713.

Prasetya Pergitawati, Ririn, Antariksa, and Abraham Muhammad Ridjal. (2014). "Perubahan Pola Ruang Dalam Rumah Lamin Adat Dayak Kenyah Akibat Pengaruh Modernisasi Di Desa Pampang, Samarinda." Arsitektur E-Journal 7 (2): 90-101.

Rini Dwi Ari, Ismu, and Antariksa. (2005). Studi Karakteristik Pola Permukiman Di Kecamatan Labang, Madura. Jurnal ASPI 4 (2): 78-93.

Singarimbun, Masri. (2013). Beberapa Aspek Kehidupan Masyarakat Dayak. ” Humaniora, no. 3: 139-50. https://jurnal.ugm.ac.id/jurnal-humaniora/article/view/2083/1883.

Sugiyono. (2015). Metode Penelitian Kombinasi (Mixed Methods). Bandung: Alfabeta.

Sulisthio, Ivan, and Esti Asih Nurdiah. (2013). "Fasilitas Ecomuseum Suku Dayak Kenyah Desa Pampang Di Samarinda.” JURNAL EDiIMENSI ARSITEKTUR 1 (2): 225-32.

Sumintardja, D, (1981).Kompedium Sejarah Arsitektur. Yayasan Lembaga Penyelidikan Masalah Bangunan, Bandung.

Tri Adiputra, IGN, Sudaryono Sudaryono, Djoko Wiyono, and Ahmad Sarwadi. (2016). "Konsep Hulu-Teben Pada Permukiman Tradisional Bali Pegunugan/Bali Aga Di Desa Adat Bayung Gede Kecamatan Kintamani Kabupaten Bangli, Bali." Forum Teknik 37 (1): $14-31$.

Wibawa, I. Putu Sastra, F. X.Adji Samekto, and I. Putu Gelgel. (2019.) Determination of the Sacred Space Uluwatu Temple with the Gis Approach. International Journal of Scientific and Technology Research 8 (11): 954-58.

Wicaksono, Bambang, and Susilo Kusdiwanggo. 2016. "Modus Bermukim Masyarakat Riparian Sungai Musi Palembang. Historical Continuity for Sustainable Future, 11-20. 